\title{
Plant occurrence on burning coal waste - a case study from the Katowice-Wełnowiec
} dump, Poland

\author{
Justyna Ciesielczuk, Andrzej Czylok, Monika J. Fabiańska, Magdalena Misz-Kennan \\ Faculty of Earth Sciences, University of Silesia, Będzińska Str. 60, 41-200 Sosnowiec, Poland \\ E-mail address (corresponding author): justyna.ciesielczuk@us.edu.pl
}

\begin{abstract}
Coal-waste dumps superimposed on former rubbish dump frequently undergo selfheating and selfignition of organic matter dispersed in the waste. The special conditions for plant growth generated as a result have been investigated since 2008 on the municipal dump reclaimed with coal wastes in Katowice-Wełnowiec, Poland. The plants observed most frequently where heating has occurred are Sisymbrium loeselii, Artemisia vulgaris, Sonchus arvensis, Chenopodium album, Achillea millefolium, Cirsium arvense, Amaranthus retroflexus, Atriplex nitens and Solanum nigrum. Some new, rare species such as Portulaca oleracea, first noticed in 2011, may be added. Most of encroaching species are annual, alien archeophytes and neophytes. Native species are mainly perennials. The majority of these species show a tendency to form specimens of huge size (gigantism). The abundance of emitted $\mathrm{CO}_{2}$ and nitrogen compounds is the likely cause of this. Additionally, the plants growing there are not attacked by insects. The heating of the ground liquidates the natural seed bank. After cooling, these places are seeded by species providing seeds at that very moment (pioneer species). Heated places on the dumps allow plant growth even in the middle of winter. As the seasonal vegetation cycle is disturbed, plants may be found seeding, blooming and fruiting at the same time.
\end{abstract}

KEY WORDS: burning coal wastes, plant gigantism, rigger differentiation

\section{Introduction}

Coal exploitation and coal-waste storage can lead to the selfheating of organic matter. The heat is produced as a result of coal oxidation. Where oxygen has access to coal and where the heat produced cannot escape, the heat cumulates to cause selfignition. Endogenic coal fires are occurring now in natural coal seams (STRACHER ET AL., 2011, 2013, 2015) and have in the past (MUSZYŃSKI ET AL., 2006). Unfortunately, they are also frequent in the coal waste dumps where the content of organic matter is significant and the dumps are badly constructed. When the fires wane, overburned places are colonized by plants.

A natural plant succession commonly occurs on coal-waste dumps (WIEGLEB \& FELINKS, 2001; NADUDVARI, 2014; ZANG ET AL., 2015). From the environmental point of view, the formation of this plant cover prevents many negative environmental impacts such as slope erosion, dust emission, and the migration of heavy metals and organic pollutants to the surroundings. By slowing runoff, plant cover prevents erosion by stabilizing dump surfaces, decreasing heavy-metal leaching by rain, and increases soil reaction (JUWARKAR \& JAMBHULKAR, 2008; BIAN ET AL., 2009; ZANG ET AL., 2015). Since coalwaste dump surfaces are commonly characterized by the presence of sulphides, heavy metals, unfavorable porosity, and low aeration and water infiltration, all inhibitors of plant growth, phytoremediation is applied (JUWARKAR \& JAMBHULKAR, 2008; SIRIVASTAVA ET AL., 2014). In some cases, bacteria and lichen living on coal-waste surfaces can act as biocatalysts of waste solubilization (SEKHOHOLA ET AL., 2013). Successful remediation and revegetation of coal-waste dumps is often difficult due to the lack of knowledge of the factors leading to soil development on anthropogenic materials. Since the current tendency is to turn reclaimed dumps into recreational areas, it is important to define what 
plant communities develop spontaneously in this anthropogenic environment, how they evolve and what dump features promote their growth.

The growth of plants on heated places in coalwaste dumps was investigated in a municipal waste dump remediated with coal waste derived from hard coal mines in the Katowice region. The dump is located in Wełnowiec, a district of Katowice on the border with Siemianowice Śląskie town, Upper Silesia. The dump has been undergoing self-heating and self-ignition and, for many years, was a source of pollution and unpleasantness for local residents. Thermal activity was observed mainly on the northern slope of the dump where the fire started at the eastern part and moved westwards. At present, the western part of the slope is the most active part (CIESIELCZUK ET AL., 2013).
Though various actions aimed at stopping selfheating in the dump considerably decreased the elevated temperatures by hundreds of degrees $\left({ }^{\circ} \mathrm{C}\right)$, the problem was not completely eliminated. In some parts of the dump, temperatures are still elevated and new spots of high thermal activity keep appearing.

The presence, migration and intensity of thermal activity, and plant behaviour and development on the dump, have been systematically observed since 2008. The dynamic of the changes taking place and the fact that living organisms occupy places with such extreme conditions, especially with regard to temperature, is somewhat surprising. The aim of our research was to recognize plant species encroaching on the heated places in the Wełnowiec dump and explain their behaviour.
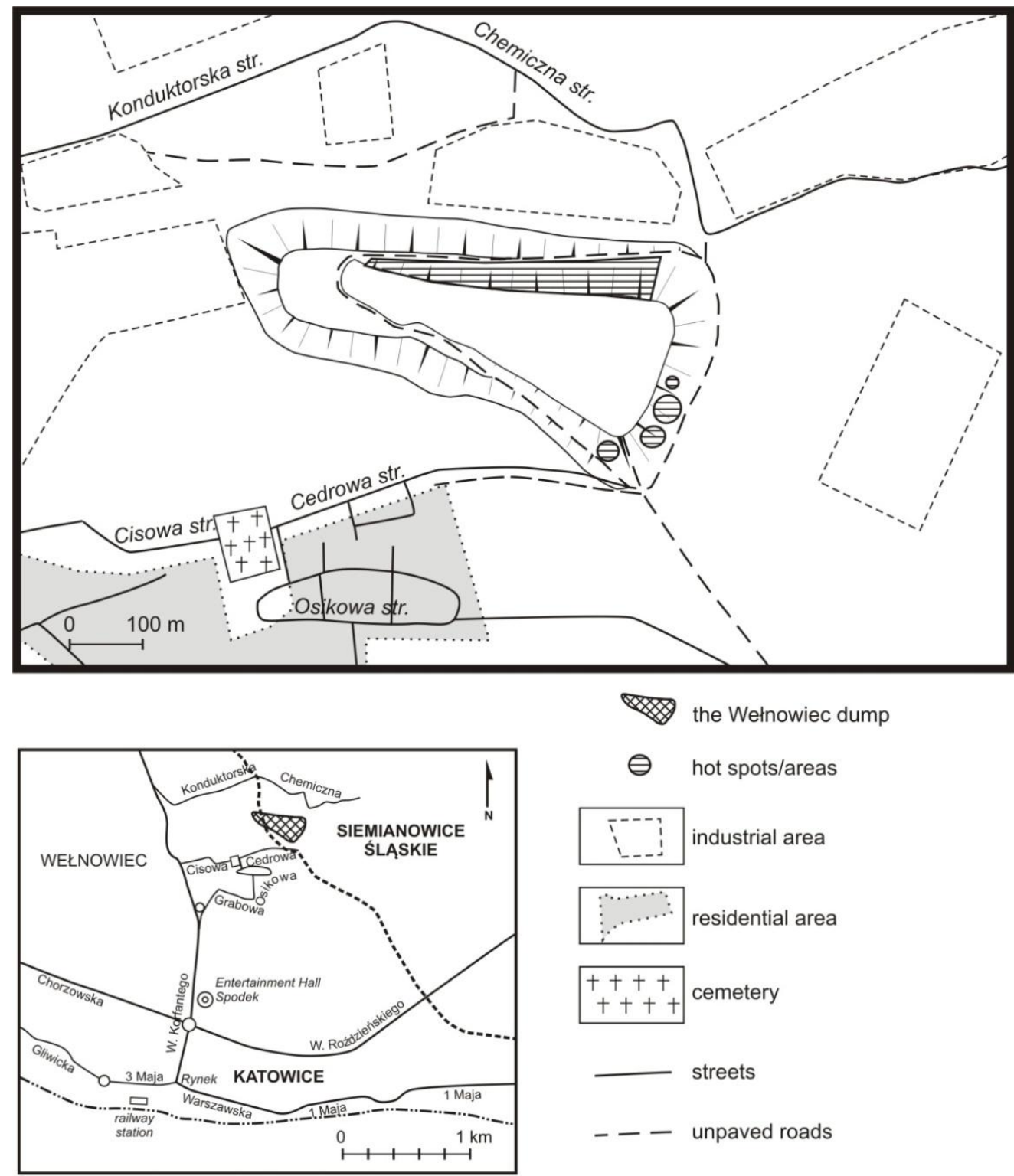

$\theta$ hot spots/areas
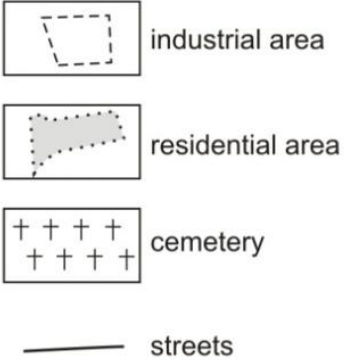

- - unpaved roads

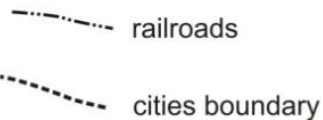

Fig. 1. Location of the Katowice-Wełnowiec municipal waste dump remediated with coal wastes. Thermally active areas are marked 


\section{Dump construction and thermal events}

The municipal dump in Katowice-Wełnowiec (Fig. 1) was opened in 1991 and closed in 1996. Some 1.6 million tons of waste comprising coal waste $(22.5 \%)$ consisting of sandstones, carbonates, siltstones and clays, municipal waste $(21.5 \%)$, rubble (40\%) and vegetable and composting waste were deposited there (KLEJNOWSKA, 1996). The dump covered an area of 16 ha and was reclaimed in 1998. As biogas was expected to be produced in the dump, 39 degassing wells were installed and methane was exploited since 2001. However, after a few years, exploitation became unprofitable.

The dump-reclamation project envisaged the construction of a multi-layer barrier system arranged on the shaped dump (KLEJNOWSKA, 1996). The layers proposed were, from top to bottom, $0.4 \mathrm{~m}$ of top soil, $0.6 \mathrm{~m}$ of coal-mine waste comprising sandstone, shale, mudstone, a coal content of $<5 \%$, and all mixed with soil (1:1), $0.3 \mathrm{~m}$ of drainage (gravel), $0.1 \mathrm{~m}$ of protection (sand), a $0.5 \mathrm{~m}$ barrier layer (clay liners), and a $0.3 \mathrm{~m}$ support layer consisting of compacted coal mine waste lying directly on the municipal waste. However, our observations show that at least the northern slope of the dump was not reclaimed according to the project plan. A much thicker cover of coal-mine waste was used and the coal waste contained much more organic matter than proposed. Large pieces of coal were frequently found. Shortly after reclamation, endogenic thermal events began to spread gradually on the slopes. This heating was accompanied by the emission of fumes, a nuisance for the residents of Cedrowa and Osikowa streets in the nearby housing estate (Fig. 1).

In recent times, thermal activity has been limited to the slopes; only in one place does it reach the top of the dump. On the eastern-and south-eastern slopes, thermal events lead to hot spots on the surface, whereas fire has gradually encroached onto the entire northern slope (Figs 1 and 2). The highest temperatures measured $30 \mathrm{~cm}$ below the surface are $260^{\circ} \mathrm{C}$ on the south-eastern slope, $460^{\circ} \mathrm{C}$ on the southern slope and $690^{\circ} \mathrm{C}$ on the northern slope (CIESIELCZUK ET AL., 2013).

\section{Methodology}

The Wełnowiec dump was monitored every month since 2008, but for the purpose of plant monitoring, four times a year, in spring, summer, autumn and winter. Temperature of the ground and $30 \mathrm{~cm}$ subsurface was measured with pyrometer ST 643 with laser sight coupled with K-probe. Representative plant specimens selected from the species association were measured in the field and collected. Stems, leaves, flowers and seeds were carefully examined in the laboratory and identification based on a number of keys (HAEUPLER \& MUER, 2000; RUTKOWSKI, 1998; SZAFER ET AL., 1986). The names of the plants are given as in MIREK ET AL. (2002).

\section{Results}

4.1. Floristic observations in the over growth of burned places

Patches of vegetation formed on the dump reflect the inclination and aspect of the dump slope, the type and humidity of the stored material and intensity of any fire. Parts of the dump which were not affected by fire are dominated by Calamagrostis epigejos with lesser amounts of Artemisia vulgaris, Tanacetum vulgare, Cirsium arvense, and Achillea millefolium. This species composition belongs to the ruderal vegetation Artemisio-Tanacetum vulgaris (MATUSZKIEWICZ, 2001). In some places, patches of vegetation from the initial stage of succession still preserved are dominated by Tussilago farfara. Native species are a major part of communities not affected by fire.

A different vegetation prevails in areas affected by fire, both in terms of vigor and species composition. Plants are larger in size and are mainly annual, e.g., Atriplex nitens, Amarantus retroflexus and Sisymbrium loeselii.

Among encroaching plants, species of alien origin dominate. There are neophytes that originally came from North America after its discovery, and archeophytes that arrived in Europe earlier, mainly from Asia (Table 1). Most of these are annual species (DAVIS, 2013). Native species encroaching on overburned areas are mainly perennials such as Cirsium arvense and Artemisia vulgaris, but annual species such as Chenopodium album are also involved (Table 1). The plants were determined on the basis of HAEUPLER \& MUER (2000) and SZAFER ET AL. (1986).

\subsection{Ecological observations}

On January 16, 2010, a new thermally active site was observed on the SW slope of the dump. The highest temperature measured with a pyrometer and a $\mathrm{K}$ probe enabling measurement to depth of $30 \mathrm{~cm}$ below dump surface, was $125^{\circ} \mathrm{C}$ (Fig. 2a). On March 11, 2010, the highest temperature measured in this part of the dump was $85^{\circ} \mathrm{C}$ on the dump surface, but $460^{\circ} \mathrm{C}$ at $30 \mathrm{~cm}$ subsurface (Fig. 2b). Mineral efflorescences of salammoniac 
and native sulfur appeared. On April 23, 2010, the temperature on the surface was $16^{\circ} \mathrm{C}$ and, $1 \mathrm{~m}$ below the surface, $260^{\circ} \mathrm{C}$. At these high temperatures, plants disappeared from an area of $15-20 \mathrm{~m}$ in diameter (Fig. 2c). In October, 2010, the temperature in that place dropped to $78^{\circ} \mathrm{C}$ at a depth of $30 \mathrm{~cm}$ (Fig. 2d) and remained so until August 2011.

Table. 1. Main species of vascular flora encroaching on burned places on the Katowice-Wełnowiec municipal waste dump remediated with coal wastes. Perennials are marked in bold and annuals in normal (names after Mirek et al., 2002)

\begin{tabular}{|c|c|c|}
\hline \multirow{2}{*}{ Native species } & \multicolumn{2}{|c|}{ Alien species } \\
\cline { 2 - 3 } & archeophytes & neophytes \\
\hline Achillea millefolium & Atriplex nitens & Amaranthus retroflexus \\
Artemisia vulgaris & Echinochloa crus-galli & Aster novi-belgii \\
Chenopodium album & Matricaria inodora & Conyza canadensis \\
Cirsium arvense & Portulaca oleracea & Sisymbrium loeselii \\
Daucus carota & Solanum nigrum & Datura stramonium \\
Picris hieracioides & Lactuca serriola & \\
Polygonum persicaria & & \\
Sonchus arvensis & & \\
Sonchus asper & & \\
Tanacetum vulgare & & \\
Verbascum thapsus & & \\
\hline
\end{tabular}

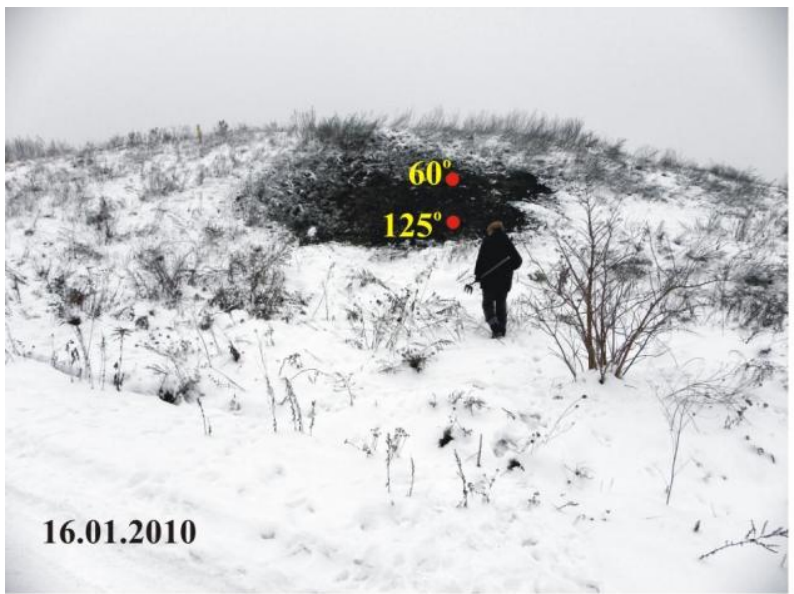

A

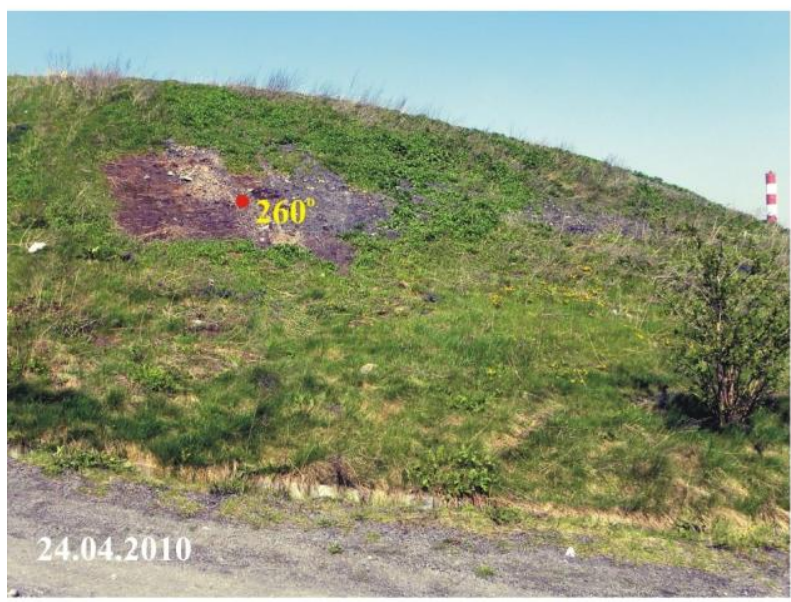

C

Fig. 2. Thermally active area on the southern slope of the Katowice-Wełnowiec dump in 2010. Temperature distribution measured $30 \mathrm{~cm}$ subsurface (J. Ciesielczuk) 
The elevated temperatures, emanating gases (mostly $\mathrm{CO}_{2}$ ) and elevated contents of nitrogen compounds in the soil result in luxuriant plant development (FABIAŃSKA ET AL., 2013). On the western edge of the heated area, rigger differentiation of encroaching plant species was observed. These plants develop profusely even outside the typical vegetation period. In the strongly heated spots, plants are absent. On the edges of the heated area, specific mosses and specific species of vascular plants appear. On May 27,2010 , the highest temperature on the heated spot at the dump surface was $60^{\circ} \mathrm{C}$, yet only $32^{\circ} \mathrm{C}$ some $50 \mathrm{~cm}$ away. In the same place, the temperature was $50^{\circ} \mathrm{C} 10 \mathrm{~cm}$ below the surface, $88^{\circ} \mathrm{C} 20 \mathrm{~cm}$ below the surface and $171^{\circ} \mathrm{C} 30 \mathrm{~cm}$ below the surface.The plants encroaching the heated spot in the dump show a diversity of dominant plant species that define the rigger pattern along the slope. With increasing distance from the heated spot, the following plants dominate (Fig. 3a): Sisymbrium loeselii, Artemisia vulgaris, Matricaria indora, Sonchus arvensis, Picris hieracioides, Achillea millefolium, Cirsium arvense.

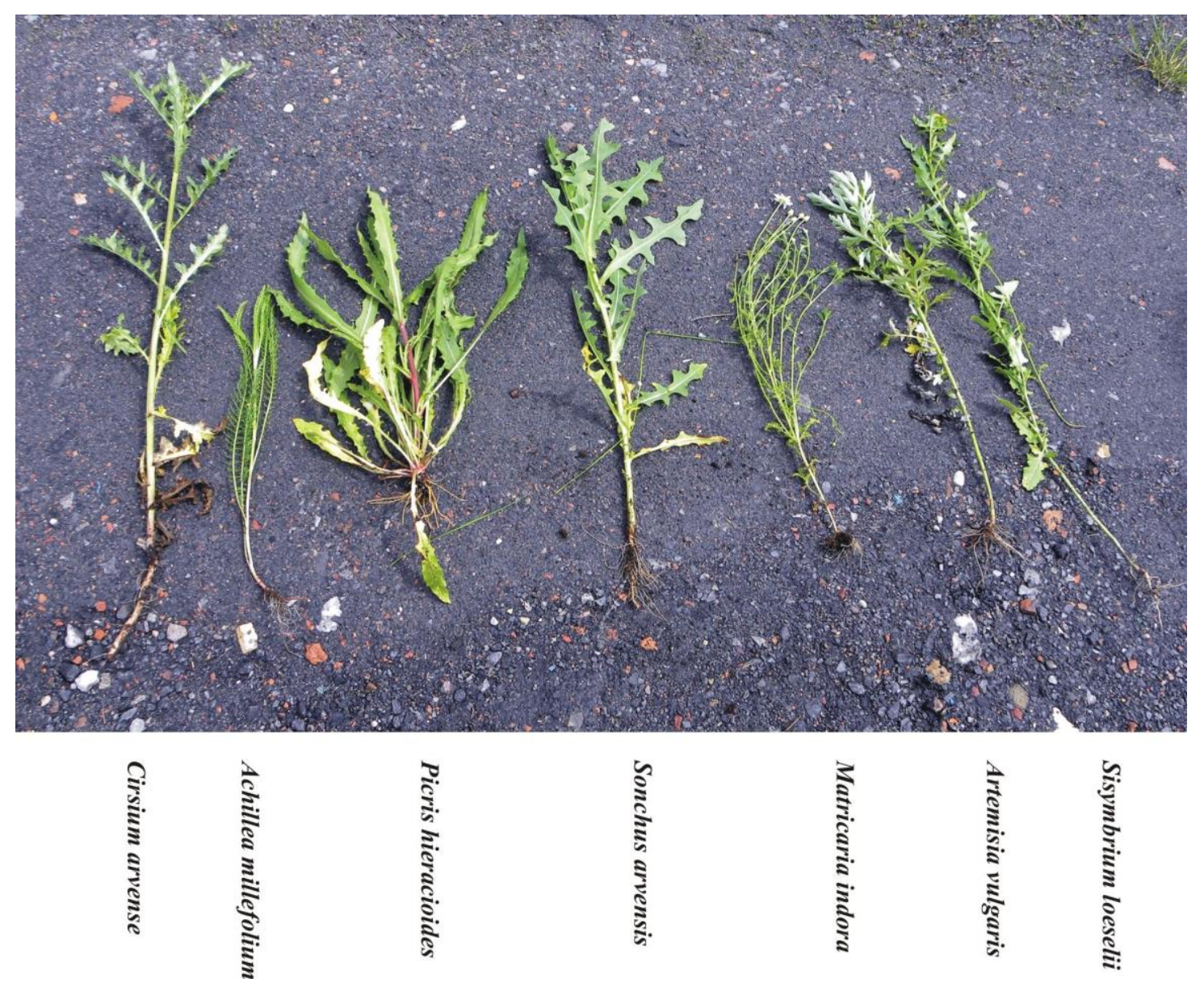

3a

In the autumn, on October 1, 2010, the spot still had an oval shape but it was smaller. Horizontally it was 7-8m in size and, vertically, 9-10 m. Odours were weak. Mineral efflorescences were absent as they had dissolved in rain water and did not re-crystallize. The temperatures measured on the dump were $30-50^{\circ} \mathrm{C}$ in the middle of the heated area on the surface and $70-80^{\circ} \mathrm{C}$ some $30 \mathrm{~cm}$ underneath. Steam was ever present.

On the edge of the hot area (0.5-1.0 m out from the border with plants), the temperature on the surface was $13^{\circ} \mathrm{C}$ and $40-49^{\circ} \mathrm{C}$ at $30 \mathrm{~cm}$ below. About $1 \mathrm{~m}$ inside the plant border, the temperature on the surface was $11-13^{\circ} \mathrm{C}$ and, $30 \mathrm{~cm}$ below, $27^{\circ} \mathrm{C}$. From that we can conclude that plants appear and develop in places where the temperature at a depth of $30 \mathrm{~cm}$ does not exceed $\sim 30^{\circ} \mathrm{C}$. In such places, the initial plant encroaching in the autumn is Sisymbrium loeselii. The riggered plant diversity was also maintained in the autumn in the heated areas as follows (Fig. 3b): Sisymbrium loeselii initial form, Chenopodium album, Amaranthus retroflexus, Cirsium arvense, Artemisia vulgaris.

On August 31, 2011, the riggered occurrence of plants around the heated place was also observed. However, the order of plants was as follows (Fig. 3c): Chenopodium album, Artemisia vulgaris, Amaranthus retroflexus, Sisymbrium loeselii. 

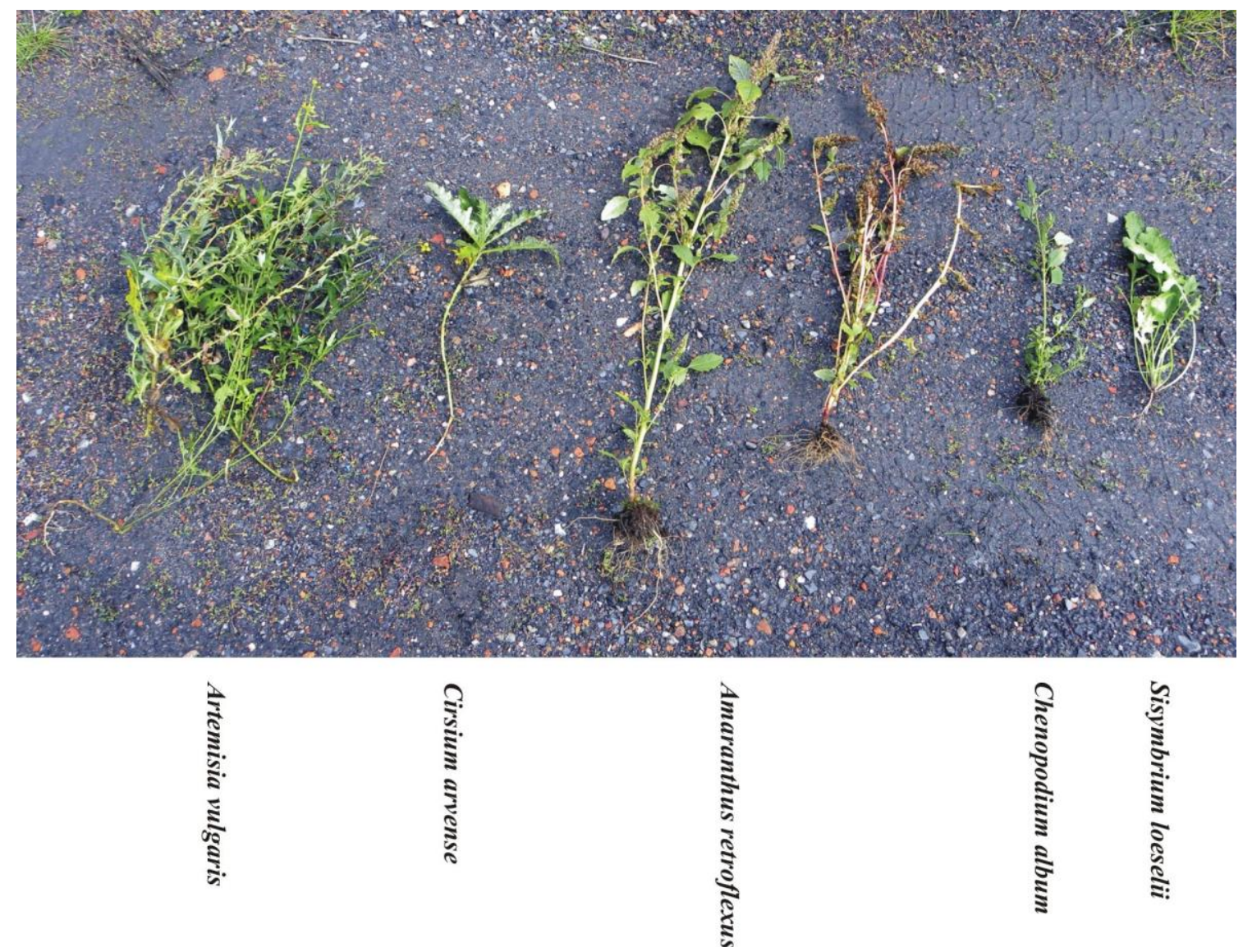

3b

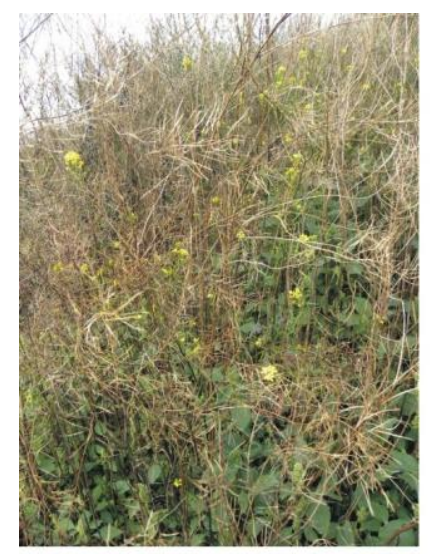

Sisymbrium loeselii

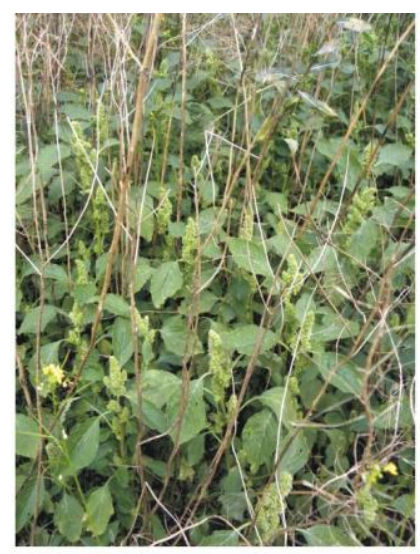

Amaranthus retroflexus

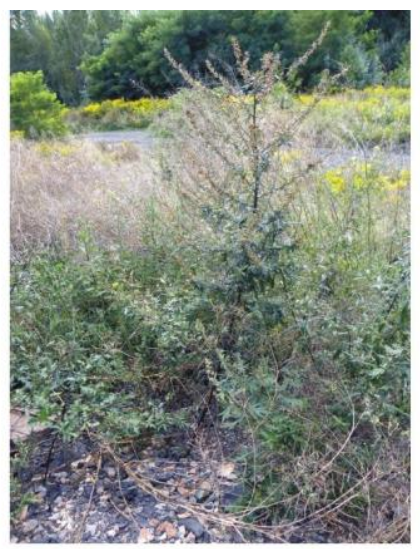

Artemisia vulgaris

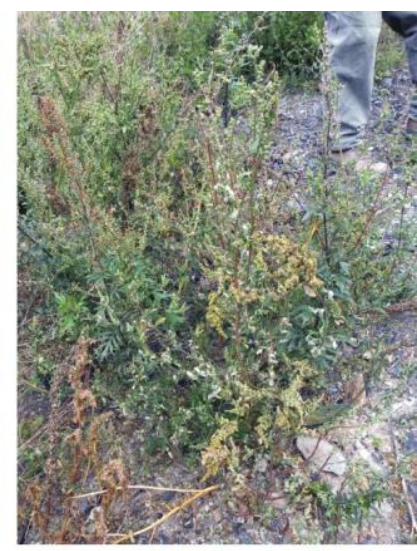

Chenopodium album 3c

Fig. 3. Plant succession at the western part of the hot spot located on the southern slope of the Katowice-Wełnowiec dump on 3a) May 27, 2010, 3b) October 1, 2010 and 3c) August 31, 2011 (J. Ciesielczuk)

A different type of plant encroachment characterizes the northern slope of the dump. This slope has been undergoing self-heating for over ten years and the temperatures rise progressively from east to west. At the end of 2009 , the central part of the northern slope was rebuilt and fires mostly ceased. After cooling, the slope was smoothened and grass was sown (Fig. 4a). By May 27, 2010, Atriplex nitens had appeared among the grass (Fig. 4b). In the summer of that same year, the plant reached a gigantic size of $2 \mathrm{~m}$ - much higher than the maximum sizes recorded for this plant growing in Poland (Fig. 4c, d). The plant caused the disappearance of grass. Sisymbrium loeselii, Chenopodium album, and Daucus carota, grew to their normal sizes. In addition, Tussilago farfara was found in the lower part of the rebuilt area. This plant is typical of the initial stages of colonization on clay soil. 


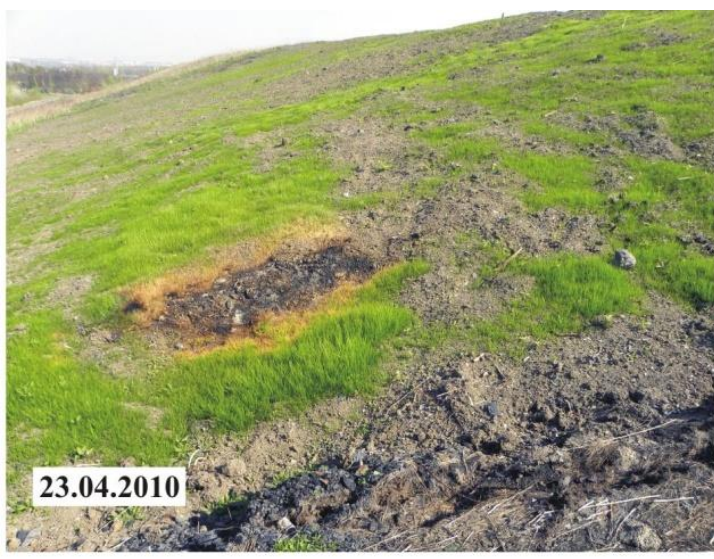

A

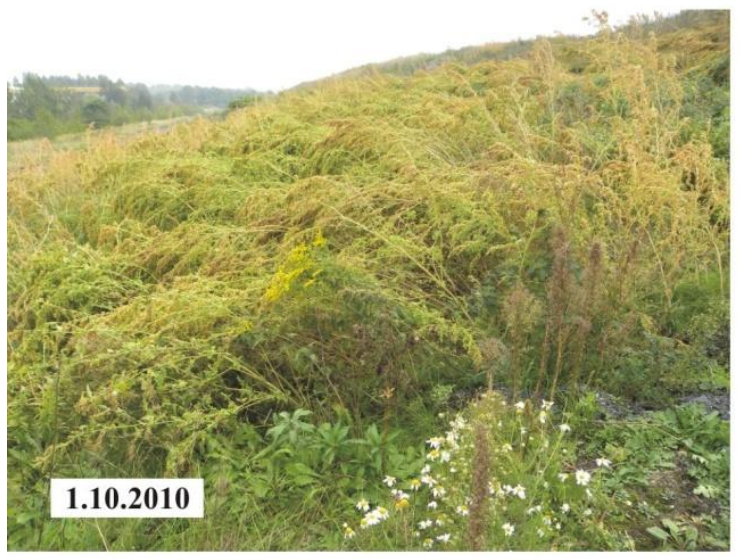

C

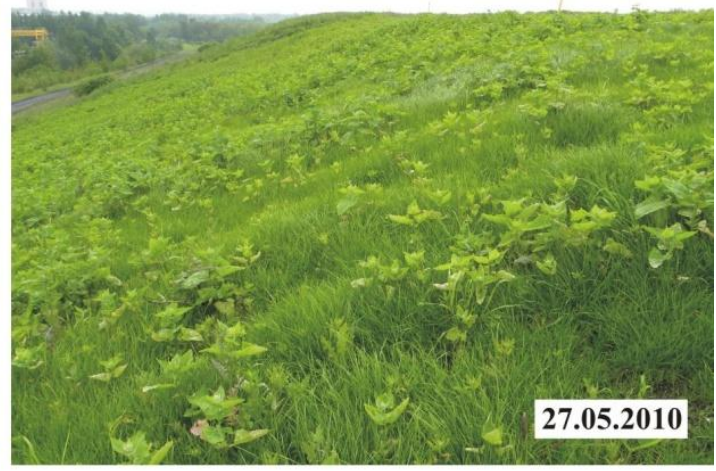

B

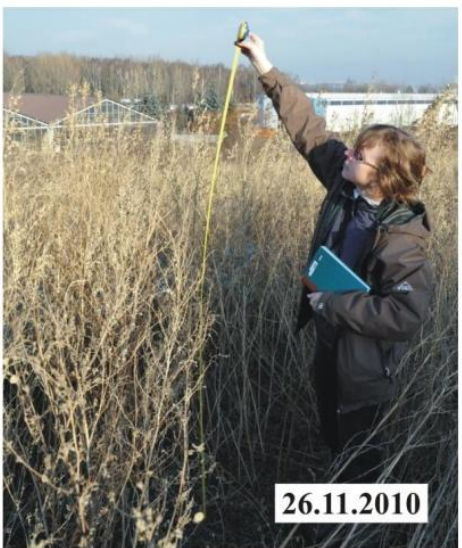

D

Fig. 4. The rebuilt central part of the northern slope of the Katowice-Wełnowiec dump. A - New grass sown on the rebuilt part of the slope; B-Atriplex nitens appearing in the grass; C, D - Domination and giant size of Atriplex nitens (J. Ciesielczuk)

The northern slope of the dump was investigated again on October 1 and November 26, 2010. The rebuilt part of the northern slope of the dump was then dominated by Solanum nigrum and Atriplex nitens, each up to $2 \mathrm{~m}$ in size. Other plants such as Artemisia vulgaris, Sonchus asper, Verbascum thapsus, and Amaranthus retroflexus also attained this size. Most of the plants here were seen to reach and even exceed their maximum sizes as given in the literature (Table 2, Fig. 5).

Table 2. Sizes of selected species observed on overburned sites in the Wełnowiec dump compared to literature data

\begin{tabular}{|l|c|c|c|}
\hline \multicolumn{1}{|c|}{ Species } & Rutkowski, 1998 & $\begin{array}{c}\text { Haeupler and Muer, } \\
2000\end{array}$ & $\begin{array}{c}\text { Heated sites } \\
\text { Wełnowiec dump }\end{array}$ \\
\hline Achillea millefolium & $25-60(-80)$ & $(20-) 40-70(-100)$ & 65 \\
\hline Amaranthus retroflexus & $10-80(120)$ & $20-120$ & 150 \\
\hline Artemisja vulgaris & $50-80(140)$ & $60-250$ & $\sim 150$ \\
\hline Atriplex nitens & $50-150(250)$ & $20-180$ & $\sim 200$ \\
\hline Chenopodium album & $20-100(300)$ & $(5-) 15-180(-300)$ & 120 \\
\hline Cirsium arvense & $50-120(150)$ & $30-150$ & 80 \\
\hline Matricaria inodora & $(15) 25-60(80)$ & $10-30$ & 60 \\
\hline Picris hieracioides & $30-80(120)$ & $30-90$ & $120-145$ \\
\hline Sisymbrium loeselii & $30-60(100)$ & $30-150$ & $\sim 60$ \\
\hline Solanum nigrum & $10-50(80)$ & $10-50$ & $\sim 100$ \\
\hline Sonchus asper & $39-80(100)$ & $30-100$ & 100 \\
\hline Sonchus arvensis & $40-150$ & $50-150$ & $\sim 200$ \\
\hline Verbascum thapsus & $(30-) 60-180(-200)$ & $30-200$ & \\
\hline
\end{tabular}




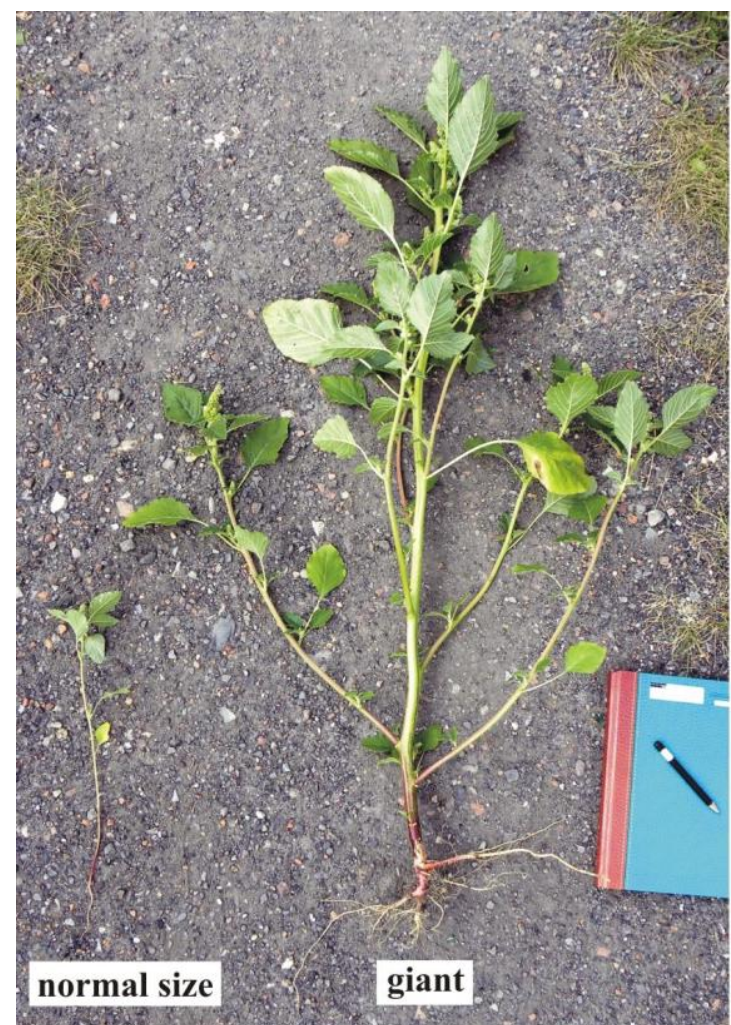

Amaranthus retroflexus

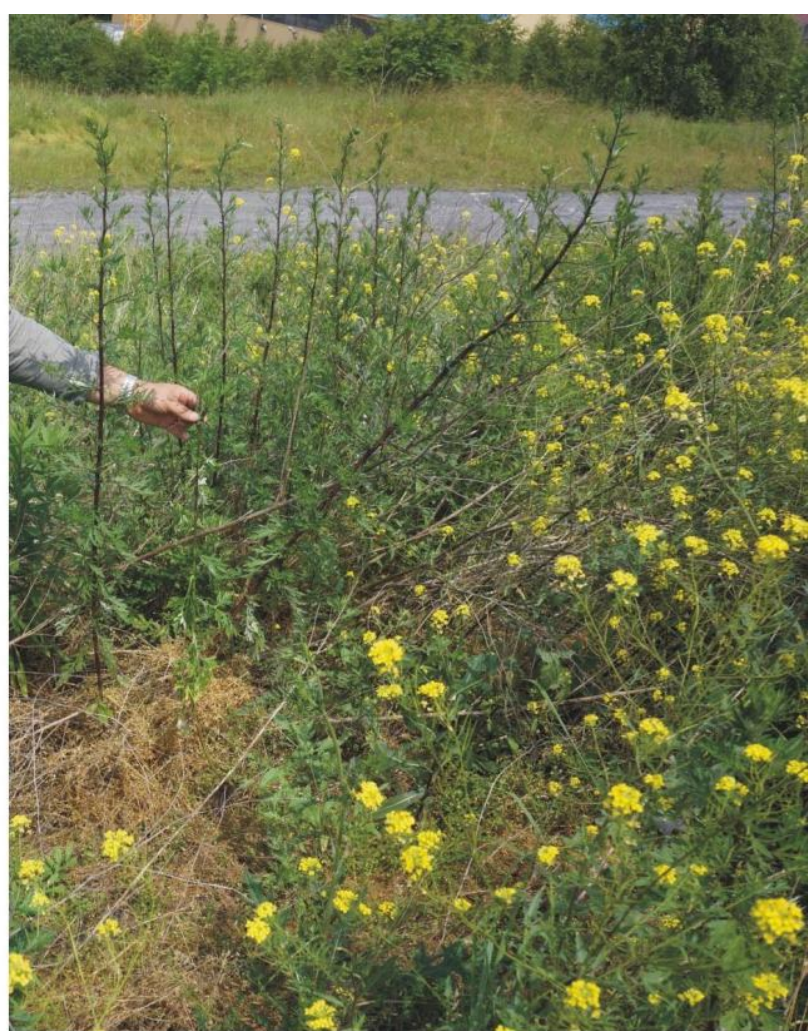

Artemisia vulgaris

Sisymbrium loeselii

Fig. 5. Examples of gigantism from the Katowice-Wełnowiec dump (J. Ciesielczuk)

The next observations on the northern slope were carried out on August 31, 2011. The heating had intensified in the upper part of the slope where the temperature at a depth of $10 \mathrm{~cm}$ below the surface was $326^{\circ} \mathrm{C}$. Parts of the plant roots were burnt. New spots without any plants had appeared in those places where, a year earlier, plants of gigantic size had been. In those places where the dump temperature allowed vegetation, the following species were identified: Sisymbrium loeselii, Chenopodium album, Amarantus retroflexus, Aster novi-belgii, Artemisia vulgaris, and Solanum nigrum. All of these plants growing on the upper part of the rebuilt northern slope of the dump were of small size. In situations where heating is intense and amounts of moisture low, the plants tend to produce fruits as fast as possible (DoER \& SHAKESBY, 2013). In intensely-heated places, the moss Syntrichia sp. appears. This moss commonly grows on thermofilous calcareous rocks and, in anthropogenic environments, on the southerlyfacing roofs of houses (VANDERPOORTEN, 2001).

Gigantism was mostly observed on the lower part of the slope that was rebuilt in order to prevent fire. The following plants were identified there: Artemisia vulgaris, Sisymbrium loeselii, Solanum nigrum, Tanacetum vulgare and rare ones of Conyza canadensis, Polygonum persicaria, Echinochloa crus-galli, and Portulaca oleracea. Portulaca is a rare plant that was seen here for the first time in 2011. Typically, its average height is $10-30 \mathrm{~cm}$ but the plants found on the dump reach much greater sizes. No trees have, as yet, encroached onto the dump.

\section{Discussion}

Several features of self-heating coal-waste dumps promote their overgrowth by plants, namely, elevated temperatures, carbon dioxide emissions, absence of vermin and, in the top parts especially, the presence of nitrogen compounds, mostly nitrates and ammonia (KOMNITSAS ET AL., 2010; GONZÁLEZ-ALCARAZ ET AL., 2011; FABIAŃSKA ET AL., 2013). High temperatures, common in Upper Silesia coal-waste dumps, is caused by zones of self-heating below the dump surface. Water expelled in the process, together with bitumen, forms wet hot areas on the dump surface (MiszKENNAN \& FABIAŃSKA, 2010). As the Wełnowiec dump is in a state of almost constant self-heating, snow cover is rather thin in winter and the growth season begins much earlier than in surrounding areas. This situation, together with ammonia nitrate acting as a fertilizer and elevated carbon dioxide concentrations, favors gigantism in plants found in the lower parts of the dump slope (Ciesielczuk et AL., 2011; FABIAŃSKA ET AL., 2013). 
Similar influences on plant growth have been recognized in tectonically active zones in the Sakhalin and Kumashir islands where gigantic herb assemblages are limited to places where faults transport heat, matter, and water to the surface (PoBEREZHNAYA \& KopANinA, 2009). Other features of these island sites which support comparison with conditions found in self-heating coal-waste dumps are soils enriched in petroleum bitumen, acid waters and a reducing soil environment. Moreover, by increasing rock surface, the fracturing of heated coal wastes, enhances the bioavailability of microelements required for rapid growth (JUWARKAR \& JAMBHULKAR, 2008.). In the Wełnowiec dump, inhibiting factors include temperatures sufficiently high to burn roots and limited water availability in dry parts of the dump.

Plants encroaching on the coal wastes are mostly foreign species (Table 1). Among them are neophytes that originally came from North America after its discovery, and archeophytes that arrived in Europe earlier, mainly from Asia. Similar encroachment by non-native species has been recognized as an ecological tendency after natural fires (DAVIS, 2013). Since high temperatures eradicate natural seed banks, re-colonization strongly depends on those plant traits which allow them to invade and spread across burnt areas, e.g., rapid and wide seed dispersal, fast sprouting and, as with annual plants, rapid plant maturation (MidGley \& Bond, 2013).

Generally, rigger plant communities developing as on the Wełnowiec coal wastes belong to anthropogenic annual- and perennial pioneering plants that are initial colonizers of ruderal terrains (MATUSZKIEWICZ, 2001; WIEGLEB \& FELINKS, 2001). They belong to the Sisymbrietalia J. TX. 1961 order. They form the patches of two associations: Sisymbrietum loeselii Gutte in Rost. et Gutte 1971 and Atriplicetum nitentis Knapp 1945. The more resistant perennial patches are formed on sites previously burned out or remote from thermally active places. They represent the associations of Onopordetalia acanthii Br.-Bl. et R.Tx. 1943, Dauco-Melilotenion Görs 1966 with patches of the Artemisio-Tanacetetum vulgaris Br.-Bl. 1931 community.

There are only a very few literature descriptions of plant communities spontaneously forming on coal wastes (e.g., WIEGLEB \& FELINKS, 2001; ALDAY ET AL., 2012; PRACH, 2013). Most describe the results of dump reclamation and focus on the difficulties of the process. Even descriptions of natural plant succession do not identify selfheating as a significant environmental factor affecting growth. Despite its overall negative impact on the environment, self-heating is a process that can promote the formation of a very unique plant cover.

\section{Conclusions}

1) Coal waste dumps form unique plant habitats that promote the development of specific plant communities. The plants reflect anthropogenic influences, and the geochemical- and mineralogical characteristics of the coal wastes. Burning parts of dumps make, as the temperature decreases, specific habitats for plants with high requirements for heat, light exposure, moisture, $\mathrm{CO}_{2}$ and nitrogen compounds.

2) The plants that occur most frequently are Sisymbrium loeselii, Artemisia vulgaris, Sonchus arvensis, Chenopodium album, Achillea millefolium, Cirsium arvense, Amaranthus retroflexus, Atriplex nitens and Solanum nigrum. Rare species may encroach on the dumps, e.g., Portulaca oleracea, observed in 2011.

3) Some of the plant species reach or exceed normal maximum sizes and can be deemed examples of gigantism. Unusually high $\mathrm{CO}_{2}$ concentrations, an abundance of nitrogen compounds, and heat, are the likely causes.

4) The lack of vermin near heated places can play a significant role in the rapid encroachment by plant species.

5) Heating eradicates the natural seed bank. After cooling, the most common is the species that seeds first and free of competition; the rule recognizing the priority of colonizer is fulfilled.

6) Heated spots are sown even in mid-winter. The yearly cycle is completely disturbed. For a given species, different plants seed, bloom or fruit at the same time.

7) Coal waste dumps are an important part of the landscape in industrial regions such as Upper Silesia. When coal waste is used to reclaim municipal waste dumps, self-heating and self-ignition can occur that is related to the organic material in the waste. Thus, avoiding the use of coal waste in reclamation is to be recommended, particularly waste with high contents of coaly organic matter.

\section{Acknowledgements:}

We would like to thank Pádhraig Kennan (University College Dublin, Ireland) for making language corrections.

\section{References}

Alday J.G., Marrs R.H., Martínez-Ruiz C. 2012. Soil and vegetation development during early succession on restored coal wastes: a six-year permanent plot study. Plant Soil, 353: 305-320. 
Bian Z., Dong J., Lei S., Leng H., Mu S., Wang H. 2009. The impact of disposal and treatment of coal mining wastes on environment and farmland. Environ. Geol., 58: 625-634.

Ciesielczuk J., Czylok A., Cebulak S. 2011. Sukcesja roślinna oraz gigantyzm obserwowane na palqcej się hałdzie $w$ Katowicach-Welnowcu,. Doc. Geonica 2011/1: 51-54.

Ciesielczuk J., Janeczek J., Cebulak S. 2013. Przebieg i przyczyny endogenicznego pożaru węgla kamiennego na zrekultywowanym składowisku odpadów komunalnych w Katowicach. Polish Geol. Rev., 61, 12: 764-772.

Davis M.G. 2013. Understanding Fire Regimes and the Ecological Effects of Fire. [in:] Belcher C.M. (ed.) Fire Phenomena and the Earth system, Chapter 6: 97-124, Wiley-Blackwell, Oxford, UK.

Doer S.H., Shakesby R.A. 2013. Fire and Land Surface. [in:] Belcher C.M. (ed.) Fire Phenomena and the Earth system, Chapter 8: 135-156, Wiley-Blackwell. Oxford, UK.

Fabiańska M., Ciesielczuk J., Kruszewski Ł., Misz-Kennan M., Blake D.R., Stracher G., Moszumańska I. 2013. Gaseous compounds and efflorescences generated in selfheating coal-waste dumps - a case study from the Upper- and Lower Silesian Coal Basins (Poland). Int. J. of Coal Geol., 116-117: 247-261.

González-Alcaraz M.N., Egea C., María-Cervantes A., JiménezCárceles F.J., Álvarez-Rogel J. 2011. Effects of eutrophic water flooding on nitrate concentrations in mine wastes. Ecol. Eng., 37: 693-702.

Haeupler H., Muer T. 2000. Bildatlas der Farn- und Blütenpflanzen Deutschlands. Verlag Eugen Ulmer Stuttgart, 1-760.

Juwarkar A.A., Jambhulkar H.P. 2008. Phytoremediation of coal mine spoil dump through integrated biotechnological approach. Bioresource Technol., 99: 4732-4741.

Klejnowska H. 1996. Projekt budowlany: Zagospodarowanie zieleniq parkowa terenu byłego składowiska odpadów komunalnych w Katowicach przy ul. Ludwika-Leopolda I i II etap. Biuro Usług Technicznych EKOTEST s.c., Gliwice.

Komnitsas K., Guo X., Li D. 2010. Mapping of soil nutrients in an abandoned Chinese coal mine and waste disposal site. Miner. Eng., 23: 610-635.

Matuszkiewicz W. 2001. Przewodnik do oznaczania zbiorowisk roślinnych Polski. PWN Warszawa.

Midgley J.J., Bond J.W. 2013. Plants Adaptations to Fire. [in:] Belcher C.M. (ed.) Fire Phenomena and the Earth system, Chapter 7: 125-134, Wiley-Blackwell, Oxford, UK.

Mirek Z., Piękoś-Mirkowa H., Zając A., Zając M. 2002. Krytyczna lista roślin naczyniowych Polski. Polish Acad. of Sci., Kraków.

Misz-Kennan M., Fabiańska M.J. 2010. Thermal transformation of organic matter in coal waste from Rymer Cones (Upper Silesian Coal Basin, Poland). Int. J. of Coal Geol., 81: 343-358.

Muszyński M., Skowroński A., Lipiarski I. 2006. Pstre utwory typu brekcji zawałowej z Kopalni Węgla Kamiennego „Marcel” (Górnośląskie Zagłębie Węglowe). Geologia: kwart. Akad. Górn.-Hutn. im. St. Staszica w Krakowie, 32, 3: 345-367.

Nadudvari A. 2014. Thermal mapping on self-heating zones on coal waste dumps in Upper Silesia (Poland). Int. J. of Coal Geol., 128-129: 47-54.

Poberezhnaya T.M., Kopanina A.V. 2009. On Causes of Gigantism in Herbaceous Plants. Russian J. of Ecol., 40: 241-246.

Prach K. 2013. Vegetation development in central European coal mining sites. [in:] Frouz J. (ed.) Soil Biota and Ecosystem Development in Post Mining Sites, Chapter 3: 38-52, Taylor \& Francis: 1-316.

Rutkowski L. 1998. Klucz do oznaczania roślin naczyniowych Polski Niżowej. Wyd. Nauk. PWN.
Sekhohola L.M., Igbinigie E.E., Cowan K.A. 2013. Biological degradation and solubilization of coal. Biodegradation, 24: 305-3018.

Srivastava N.K., Ram L.C. Ebhin Masto R.E. 2014. Reclamation of overburden and lowland in coal mining area with flyash and selective plantation: A sustainable ecological approach. Ecol. Eng., 71: 479-489.

Stracher G.B., Prakash A., Sokol E.V. (eds.) 2011. Coal and Peat Fires: A Global Perspective, Volume 1, Coal - geology and combustion, Elsevier: 1-358.

Stracher G.B., Prakash A., Sokol E.V. (eds.) 2013. Coal and Peat Fires: A Global Perspective, Volume 2, Photographs and multimedia tours, Elsevier: 1-554.

Stracher G.B., Prakash A., Sokol E.V. (eds.) 2015. Coal and Peat Fires: A Global Perspective, Volume 1, Case studies coal fires, Elsevier: 1-786.

Szafer W., Kulczyński S., Pawłowski B. 1986. Rośliny polskie, cz. I i II. PWN, Warszawa.

Vanderporten A. 2001. The Syntrichia ruralis complex in Belgium, Cryptogamie Bryol., 22 (2): 71-84.

Wiegleb G., Felinks B. 2001. Primary succession in postmining landscapes of Lower Lusatia - chance or necessity. Ecol. Eng., 17: 199-217.

Zhang L., Wang J., Bai Z., Lv CJ. 2015. Effects of vegetation on runoff and soil erosion on reclaimed land in an opencast coal-mine dump in a loess area. Catena, 128: 44-53. 